ARTICLE

\title{
Concepts, policies and actions of internationalization of Higher Education: reflections on the expertise of a North American University
}

\author{
Marlize Rubin-Oliveiral (D) \\ Hamilton de Godoy Wielewickill

\begin{abstract}
This paper aims to explore - from a decolonial point of view - concepts, policies and actions of internationalization of Higher Education at the University of Georgia based on a qualitative approach with individual semi-structured interviews, observations and documental analysis addressing two research questions about: the conceptions of internationalization of Higher Education; and how internationalization policies and actions are perceived within University of Georgia. From the analysis, three substantive categories have been identified: Subject, Place and Research. Those express concepts supporting policies and actions of internationalization. Subjects can be seen as the starting point and driving force of processes of internationalization. Places are spaces inherently filled with both contradictions and possibilities, bringing together participants who count on support and means to build bridges for understanding, by acting out interdisciplinary joint efforts of research to address complex issues affecting mankind as a whole.
\end{abstract}

KEYWORDS

internationalization; Higher Education; decolonial thinking.

'Universidade Tecnológica Federal do Paraná, Pato Branco, PR, Brazil.

"Universidade Federal de Santa Catarina, Florianópolis, SC, Brazil. 


\title{
CONCEITOS, POLITICAS E AÇÕES DE INTERNACIONALIZAÇÃO DA EDUCAÇÃO SUPERIOR: REFLEXÕES SOBRE A EXPERIÊNCIA DE UMA UNIVERSIDADE NORTE-AMERICANA
}

\begin{abstract}
RESUMO
Este artigo visa explorar - por meio de um olhar decolonial - conceitos, políticas e ações de internacionalização da educação superior na Universidade da Geórgia com base em uma abordagem qualitativa de pesquisa, com entrevistas individuais semiestruturadas, observações e análise documental abordando duas questões de pesquisa sobre: concepções de internacionalização da educação superior e como políticas e ações de internacionalização são percebidas na Universidade da Geórgia. Por meio da análise, três categorias substantivas foram identificadas: sujeito, lugar e pesquisa. Estas, por sua vez, expressam conceitos que sustentam políticas e ações de internacionalização. Os assuntos podem ser vistos como ponto de partida e força motriz dos processos de internacionalização. Lugares são espaços inerentemente repletos de contradições e possibilidades, reunindo participantes que podem contar com apoio e meios para construir pontes para a compreensão, atuando em esforços conjuntos interdisciplinares de pesquisa para abordar questões complexas que afetam a humanidade como um todo.
\end{abstract}

\section{PALAVRAS-CHAVE}

internacionalização; educação superior; pensamento decolonial.

\section{CONCEPTOS, POLITICAS Y ACCIONES DE INTERNACIONALIZACIÓN DE LA EDUCACIÓN SUPERIOR: REFLEXIONES SOBRE LA EXPERIENCIA DE UNA UNIVERSIDAD ESTADOUNIDENSE}

\section{RESUMEN}

Este artículo explora - desde un punto de vista decolonial - conceptos, políticas y acciones de internacionalización de la educación superior en la Universidad de Georgia, basado en un enfoque cualitativo de investigación, con entrevistas individuales semiestructuradas, observaciones y análisis documental abordando dos cuestiones de investigación sobre: concepciones de internacionalización de la educación superior y cómo se perciben las políticas y acciones de internacionalización en la Universidad de Georgia. A partir del análisis se identificaron tres categorías sustantivas: sujeto, lugar e investigación. Esos conceptos expresos apoyan políticas y acciones de internacionalización. Los asuntos pueden ser vistos como el punto de partida y la fuerza motriz de los procesos de internacionalización. Los lugares son espacios intrínsecamente llenos de contradicciones y posibilidades, que reúnen a participantes que cuentan con apoyo y medios para construir puentes para la comprensión, actuando en esfuerzos conjuntos interdisciplinarios de la investigación para abordar problemas complejos que afectan a la humanidad en general.

\section{PALABRAS CLAVE}

internacionalización; educación superior; pensamiento decolonial. 


\section{INTRODUCTION}

Internationalization is a Subject of research of growing interest in the context of Higher Education studies, mainly due to the impacts of globalization on processes within institutions along the past few decades, as consistently demonstrated by several studies on globalization of Higher Education (Altbach, 2004; Jones et al., 2016; Zajda and Rust, 2016). A common thread connecting those studies is the notion that the globalization of the economy has played a key role in driving Higher Education to move forward in the challenge of drawing up internationalization policies and actions.

The international dimension and the position of Higher Education institutions in the global arena have been given considerably greater emphasis in international, national and institutional documents and mission statements than ever before. In that context, two Higher education movements beginning in the 1990s contributed to intensify the debate about internationalization. The first one was the creation, dissemination and widespread acceptance of world rankings of universities alongside with the formulation of the concept of world-class universities (Altbach and Salmi, 2011; Hazelkorn, 2011; Jones et al., 2016; Salmi, 2009). The second one has to do with the European movement to unify Higher Education through the so-called Bologna Process (Froumin and Lisyutkin, 2015; Wielewicki and Rubin-Oliveira, 2010; Wit, 2011). Both movements have given rise to research and debate with different approaches and from diverse perspectives.

The internationalization of Higher Education is rising in strategic importance among associations of Higher Education all over the world. A 2013 European University Association (EUA) membership survey (EUA, 2013) indicates that most European universities have either thought strategically about internationalization, or have a strategy in Place, and/or want to enhance and improve that strategy. The EUA (EUA, 2013) has been supporting European universities to strategically internationalize through a number of projects and dedicated services. That support includes projects such as the Mapping University Mobility of Students and Staff (MAUNIMO); the Academic Links and Strategic Internationalization of the Higher Education Sector (ALISIOS); and the Framework for the Internationalization of Doctoral Education (FRINDOC). Besides that, the Horizon 2020 (Horizon, 2018) is an EUA Research and Innovation program with the consistent funding of nearly $€ 80$ billion available over a 7-year-period (2014 thru 2020), in addition to investment that this remarkable amount of funding will attract, "it promises more breakthroughs, discoveries and world-firsts by taking great ideas from the lab to the market" (Horizon, 2018).

In the United States, Mapping (ACE, 2017) is the research project of the American Council on Education (ACE)'s Center for Internationalization and Global Engagement (CIGE), currently in its fourth edition. CIGE provides analysis of critical international education issues and administers programs and services to support Higher Education institutions' internationalization and global engagement strategies. A core principle underpinning CIGE's research and programs is "comprehensive internationalization", defined by CIGE (ACE, 2017,p. 1) as "a strategic, coordinated process that seeks to align and integrate international policies, programs, and initiatives to position colleges and universities as more globally oriented and internationally connected institutions". 
In Latin America, the Conferencia Regional de Educación Superior (CRES, 2018), a relevant movement - not only from a macro-regional perspective, but also from a worldwide point of view -, has held three region-wide conferences: the first one in Havana (Cuba), in 1996; the second one in Cartagena (Colombia); and the third one in Cordoba (Argentina), in 2018. The conferences have been dedicated to organizing the particular issues and interests of Higher Education in Latin America and the Caribbean in a more integrated and concerted way. Its importance lies upon its mobilizing and engaging potential and its focus on the preparation for the worldwide conference held by the United Nations Educational, Scientific and Cultural Organization (UNESCO), with likely impacts on Higher Education research and policy-making all over the world.

Despite their differences in focus, scope and approach, all of those movements seem to share a kind of commonly accepted definition of internationalization as the process of integrating an international, intercultural or global dimension into the purpose, functions (primarily teaching/learning, research, service) or delivery of Higher Education (Knight, 2004). Those movements also influence the definition of policies and actions within institutions, with direct and indirect impact upon academic life.

In Brazil, differently, for example, from the United States, the regulation of the Higher Education system as a whole is strongly centralized by federal government, with relative autonomy at the institutional level. There is a wide range of institution types, student populations, and other characteristics. From those movements on, the strategic plans of the universities began to be elaborated in order to reach those new demands of internationalization, even by beginning to be a relevant part of the process of institutional evaluation by the government, with impacts and consequences on public funding available to universities, both public and private. ${ }^{1}$ From the perspective of policy-making, internationalization of Higher Education plays a major role in building strategies for attracting and retaining human resources working in fields in which the production and circulation of knowledge are implied, such as universities and research institutions and facilities. New challenges of the so-called globalized society, like the advancement of the knowledge economy and labor mobility, have confronted the university to react as far as internationalization is concerned. This process of connecting internationally is in the very roots of the concept of what a university is. Since the very beginning of their history, universities have relied heavily upon mobility and international agreements and interactions to perform their mission, but over the past few decades or so, the nature, the intensity and the reach of such phenomena have increased so dramatically that the challenges have changed likewise.

Due to the relevance of internationalization and to the complexities involved, the main objective of this paper is to explore concepts, policies and actions

1 In Brazil, the major distinction between universities has to do with funding: with two basic kinds of universities: public or private. Public universities are maintained and funded by the government and are, by definition, tuition-free. Private institutions, on the other hand, depend mainly on tuition as their most important source of funding, but are also eligible to access public funding, especially the ones related to research and special undergraduate and graduate programs. Not as requirement, but rather as a consequence of this model of funding, public universities tend to concentrate the most prepared faculty, most graduate programs and about $90 \%$ of the research carried out in Brazil. 
of internationalization of Higher Education by taking into account the context of a university which resembles some of the features and characteristics of Brazilian public universities. Due to that, we conducted an exploratory study at the University of Georgia (UGA) as part of a visiting scholar program, with the support of another researcher coming from Brazil specifically to assist the research activities in Athens (GA). This research is part of a larger project called "Challenges of Internationalization of Higher Education: World-Class Universities". ${ }^{2}$

We seek to support our analysis from a decolonizing approach (Dussel, 1986, 1977; Freire, 2015; Mignolo, 2017; Peters, 2017; Santos, 2015). We understand this approach as pluri- or multi-universal rather than universal, which is not meant to be the only option, but one among many possibilities that could even be put to work together. In that respect, Dussel (1977) argues that difference and distinction do not have the same meaning. Beings, things, and possibilities are multiple, different. In that sense, the decolonial cosmopolitanism should be thought of as cosmopolitan localism (Mignolo, 2017).

The possibility of exploring the theme of internationalization from an immersion within the context of UGA was intended to work as a kind of self-reflective mechanism about similar issues and challenges faced in the Brazilian context, rather than a case study. ${ }^{3}$ We understand that by exploring in depth the theme of internationalization through experiencing everyday-life aspects at another institution, we could extend and improve the possibilities of analysis and self reflection about our context. Rather than a contemplative look, this study purports to construct substantive categories that could be meaningful and relevant to the Brazilian and Latin American due mainly to the recognition of other as distinct from self, thus implying an acknowledgment of its value for the possibility of establishing a dialogic, non-hierarchical relationship.

\section{METHODOLOGICAL APPROACH}

The decolonial perspective assumed in this paper argues for a researcher's point of view of the other as distinct, indicating methodological choices that allow for the learning on how to situate oneself so that, from the possibility of revelation, one could come to a sensible interpretation of the other's distinct experiences (Dussel, 1986). This study has been based on a qualitative and exploratory design, which requires the researcher to act as the main instrument to accomplish the objective of exploring internationalization concepts, policies and actions (Bogdan and Biklen, 2017; deMarrais, 2004; Maxwell, 2013; Minayo, 2000). Reality is made of layers and the utmost important task of the researcher relates to searching for apprehending beyond the visible, penetrating other levels that interact with each other and that make social reality highly complex (Minayo, 2000).

2 This research is funded by CNPq/Brazil, grant 446097/2014, Edital Universal 14/2014.

3 A case study has the uniqueness of the context as a sine qua non condition. Our understanding is that the main reason to study internationalization from the context of UGA does not refer to any singularities of that particular university besides whatever was mentioned earlier. 
Within that particular theoretical scenario, the choice for interviews in this study is mainly based on the idea that "qualitative interviews are used when researchers want to gain in-depth knowledge from participants about particular phenomena, experiences, or sets of experiences"(deMarrais, 2004, p. 52).

The first contacts with the institution were made through the Office of International Education (OIE) at UGA. That initial contact via email started with the presentation of the objectives and purposes of the research and a general idea of the kind of research work we had in mind. Based on that preliminary set of information, the agenda of interviews and participants was indicated and set up by the OIE. Interviews were carried out by the two researchers and were held in the offices of participants from February $5^{\text {th }}$ thru $8^{\text {th }}, 2018$ (Table 1).

Table 1 - Data collection sources.

\begin{tabular}{|c|c|c|}
\hline Interviews & Document Analyses & Observation \\
\hline $\begin{array}{l}\text { Provost }(\mathrm{n}=1) \\
\text { Faculty and directors }(\mathrm{n}=8) \\
\text { Staff }(\mathrm{n}=2)\end{array}$ & \multirow{2}{*}{$\begin{array}{c}\text { Institutional mission } \\
\text { and vision statement } \\
\text { Strategic plan } \\
\text { Office International Education } \\
\text { Institutional website }\end{array}$} & \multirow{2}{*}{$\begin{array}{l}\text { International program } \\
\text { and social events } \\
\text { Physical involvement }\end{array}$} \\
\hline $\begin{array}{l}\text { Female }(\mathrm{n}=4) \\
\text { Male }(\mathrm{n}=7)\end{array}$ & & \\
\hline
\end{tabular}

Source: Research data (2018).

Elaborated by the authors.

Data were collected from 11 individual semi-structured interviews (lasting 40 minutes on average) and all participants signed the informed consent form of research. The strategy used by the researchers was notetaking of interview responses, with immediate follow-up discussion between the researchers about those notes, so as to produce a third set of them, representing an overall, mutually agreed, interpretation of the notes taken.

As a research tool, an interview is understood here from a decolonial perspective as an intentional way of learning about people's feelings, thoughts, and experiences. The basic assumption is that "Interviewers work in local contexts and are informed by their own and others' racial, ethnic, cultural, and national origins"(Roulston, 2010,p.115). For the purposes intended, two research questions have been structural to every interview:

1. What are the conceptions of internationalization of Higher Education at the university?

2. How are internationalization policies and actions perceived within the scope of the institution?

Categorial organization (Maxwell, 2013) was built from the research questions. Conception, policies and actions worked as the initial categories that served to organize the interviews and document analysis. The systematic summary notes have been placed into these three categories.

On organizational grounds, we assume that the analysis begins as soon as the researcher starts the field work (Bogdan and Biklen, 2017). In this work, data 
collected were analyzed at two levels: analysis during data collection and analysis after data collection. Data analysis in the first phase was carried out simultaneously and continuously both in and outside the field. This meant that the researchers carried out analysis while observations were ongoing.

During interviews, researchers had the opportunity to obtain the indication of documents that could be useful for the analysis. Those documents were important to build the triangulation of the research data with the notes of the observations. Such triangulation basically aimed at establishing an interaction with the meaning-making process, to allow for going beyond the surface level of whatever was said, written, seen or observed. In that respect, therefore, we align to a decolonial assumption of such term. All the data collected were arranged in the form of field notes and tables for data understanding and analysis, looking for meaning, themes and patterns for interpretation to determine the three substantive categories (Maxwell, 2013) - Place, Subject and Research.

\section{CONTEXT OF THE RESEARCH}

In the very origins of UGA, its commitment to the general good of society is deeply rooted into the mission statement of the university. The state of Georgia became the first one in the United States to charter a state-supported university. In 1784, the General Assembly had set aside 40,000 acres of land to endow a college or seminary of learning (UGA, History, 2018). Consequently, this commitment is translated into how UGA connects with communities in a very broad sense. To name a prototypical instance of such connection, Public Service and Outreach are central to the University's mission, spearheading UGA's extensive outreach [efforts through a number of units,] which include the Carl Vinson Institute of Government, the J.W. Fanning Institute for Leadership Development, the Archway Partnership, the Small Business Development Center, the State Botanical Garden of Georgia, the Georgia Center for Continuing Education, the Office of Service-Learning and UGA Marine Extension/Georgia Sea Grant, reaching all 159 counties and more than 500 cities [of Georgia] (UGA, Facts, 2018).

The mission of UGA underlines that, due to its nature "with statewide commitments and responsibilities, [it] is the state's oldest, most comprehensive, and most diversified institution of Higher Education" (UGA, 2012). More than a statement frozen in time, it expresses a sense of duty and of accomplishment facing the fact that it is ranked America's n. 1 public flagship university for $\mathrm{PhDs}$ awarded to African-Americans, ${ }^{4}$ a remarkable figure originated in part to an increasingly diverse student body and a commitment to student success made by the university. That explains why "UGA is one of the 83 recipients of the 2016 INSIGHT - Into Diversity Higher Education Excellence in Diversity Award [...] for the third year in a row, [which is a proof of the] national recognition for its efforts to foster an inclusive,

4 Over the five-year period covered in the latest National Science Foundation Survey of Earned Doctorates, UGA awarded 143 doctoral degrees to African-Americans (UGA, Office of Institutional Diversity, 2018). 
diverse campus". The measures of UGA's success in issues of diversity is mirrored in the six-year graduation rate for African-American students, which is of 87 percent, more than the double of the national average, according to the National Center for Education Statistics. The graduation rate of 80 percent for Hispanic students also exceeds by far the national average (UGA, Office of Institutional Diversity, 2018).

The diversity present in the university can bring new and different perspectives into the institution, so that the increasing diversity within the institution is seen as a space of relevant and necessary contradiction for the university, in accomplishing its commitment to change the world. Santos (2015) drew attention to the fact that at no point in human history have we been so diverse in such small physical spaces. In this way, tensions and contradictions can bring us unique possibilities in the history of human production, in terms of the possibilities to rethink consolidated practices and concepts as a single monolithic truth.

Besides the commitment to enact an important role for the communities that provide with their effort some of the means for its existence, the university is also highly committed to "expanding and deepening UGA's global connections. International education and service learning efforts" [are thought of as a way to expand the participation of UGA in different areas of the globe] "while providing new opportunities for all three missions - instruction, research and service" in an articulated, purposeful and intentional way which assumes that by "maintaining study abroad enrollments, the University's priorities are to increase engagement in global research and to collaborate with agencies within our state to help Georgia compete successfully in the global marketplace"(UGA, 2012, p. 2). Table 2 presents a brief overview of data which translate the importance and scope of action of UGA for the analysis purported in this study.

Table 2 - University of Georgia by numbers.

\begin{tabular}{l|c}
\hline Founded & 1785 \\
\hline Faculty (instruction/research/public service) & 3,060 \\
\hline Administrative/other professional & 4,475 \\
\hline Technical/clerical/crafts/maintenance & 3,130 \\
\hline Undergraduate & 28,848 \\
\hline Graduate/professional: & 8,758 \\
\hline Living alumni & 310,000 \\
\hline International scholars & 805 \\
\hline International students & 2391 \\
\hline Student abroad & $+2000 /$ year 6\% \\
\hline Countries partnerships & 55 \\
\hline & Cortona - Italy (1970) \\
Abroad programs & Costa Rica - Monte Verde (2002) \\
& Oxford - United Kingdom (2014) \\
\hline
\end{tabular}

Source: UGA (UGA by the numbers, 2018). 


\section{INTERNATIONALIZATION OF HIGHER EDUCATION: CONSTRUCTION OF SUBJECTS AWARE OF THEIR PLACE}

Subjects ${ }^{5}$ are at the center of all processes. All interviewees affirmed the importance of individual Subjects' initiatives. The relationship between Subjects in the research process is at the genesis of all institutional agreements. The assumptions of modernity (Mignolo, 2017; Santos, 2015) brought a set of ideas among which it was claiming to eliminate the importance of the Subject and of personal relationships on behalf of the advancements of science. However, what is evident in the collected data is that the Subjects see themselves as protagonist Subjects (Freire, 2015), characterized as autonomous, able to propose and to ask questions.

All the interviews revealed the autonomy of the Subjects to seek for desired international partnerships. The ones in charge of proposing and sustaining international agreements and partnerships are the individual Subjects. All of them affirm that there is no institutional requirement in the literal sense of the word, but, rather, there is support and structure to pursue the goals they feel committed to. However, they also point out the visibility and prestige achieved from engaging in international agreements and their tendency to impact one's career within the university and beyond.

One has to consider, however, that there are indeed research areas and themes that are highly visible and, hence, tend to have greater capacity to "capture" resources and to foster connections worldwide than others. All interviewees in managerial positions were absolutely clear in expressing an understanding that institutional policies always begin with the initiative of individuals. This understanding echoes by all faculty interviewed, as well as in the documents analyzed. The usual pattern is that the proposition of partnership starts from existing contacts, usually initiated by joint research and outreach efforts. One example of this pattern, translated into institutional documents is that "Cooperative agreements are formal, legal agreements between UGA and a partner institution that allow more extensive and effective forms of collaboration" (UGA, Initiating academic partnerships, 2018). This, in turn, seems to create a sense of belonging that could be synthesized in a quote of one of the interviews, that translates an urge to take part of the whole process by stating that "if I do not participate in the takeoff, I do not want to arrive at the landing" (Director 8), as if once one engages in international activities, one should go deeply into that process.

The trust and the ethics of the Subjects and institutions involved in the search for solutions were identified as fundamental in the agreements, especially when there are compatibility issues between the systems. One of the interviewees, when explaining agreements and partnerships, emphasizes that "it is not the prestige of the institution that moves the agreements, but the adequate mobilization of the

5 Although we are aware of the usual, recurrent meanings to the word "subject" in english, in respect to our analytical purposes, epistemological background, and cultural reference, we will resort to Paulo Freire's concept of Subject, which implies an idea of critical, committed engagement with the social processes one gets involved with. 
Subjects and interests with confidence and ethics"(Director 7). The administrative structures and processes of each institution involved tend to be diverse and raises the need to access and nurture the personal ability and willingness of institutions to find effective possibilities for building agreements and partnerships that are mutually interesting and consensually constructed. In this way, the sensitivity of the Subjects is fundamental for the internationalization of Higher Education within the scope of the institutions involved.

In terms of process management, we have identified as absolutely fundamental in the internationalization of Higher Education the ability of Subjects to interpret regulations in order to accommodate the needs of both legislation and individuals. It was possible to identify a deep sensitivity of the Subjects in relation to their role in accompanying and deliberating on the lives of other Subjects. This is particularly true in situations of vulnerability or fragility to which many immigrants are submitted to for a number of reasons that range from personal to political. One of the interviewees (Director 5) was clearly impacted when reporting a case in which she had to advise a $\mathrm{PhD}$ student not to leave the country to visit his sick mother (who eventually passed away the following week) under the penalty of not being able to return to the USA due to undesired changes in the immigration process. The statement reveals the term "world sensibility" used by Mignolo (2017) when referring to the possibility of constructing a decolonial approach, that integrates Subjects rather than denying them, as characteristically done along modern rationality.

We are aware that globalization (Santos, 2015) suffocates the notion of solidarity, returning mankind to the primitive condition of individuals standing alone, as if we were to deny what there is of humane in ourselves. It also reduces the notions of public and private morality to almost nothing. However, what we find here is a situation of sensitivity, intentionally required by a decolonial approach (Mignolo, 2017; Santos 2015), which needs to be clothed with meanings of the Subjects of the process.

The Subject category is highlighted as a substantive category because it was possible to identify in the interviews - for all Subjects - a deep awareness of their position in the institution. In addition, they seem to understand in depth the mission of UGA, as stated that "The University of Georgia, a land-grant and sea-grant university with statewide commitments and responsibilities, is the state's oldest, most comprehensive, and most diversified institution of Higher Education"(UGA, 2012).

The second substantive category at the center of the process of internationalization of Higher Education is Place.

The return to the local should inspire the means for encouraging an openness toward the past colonial experience and an openness toward future that does not preclude new ways of thinking and doing. In this sense the postcolonial university is not simply the university institution after the end of colonial period, at the beginning of independence, but an attempt to rethink the institution of the university that divests it of its colonial forms and opens up new possibilities for becoming a different kind of institution. (Peters, 2017, p. 6) 
All interviewees showed deep awareness of the Place they occupy within the institutional mission in the strategic plan, and referred to it in the interviews. In addition to being knowledgeable about UGA's role for the Georgia State community, they are deeply knowledgeable about their role in this context. The importance of internationalization for UGA is emphasized, but what stands out is the strategy of preserving the institutional mission of commitments with the state of Georgia.

In terms of institutional policies, all the interviewees highlighted their role in expanding UGA's international insertion. Some even mentioned the fact that they were hired for specific functions to subsidize information processes for decision making regarding investments in internationalization. The OIE is now a central Place for the internationalization of UGA. Individual initiatives are strengthened and made feasible with the assistance of the office. This is recognized by the interviewees for their importance in managing the processes.

As Knight (2004, p. 25) argues,

social and cultural logics, especially those related to the promotion of intercultural understanding and national cultural identity, are still significant when it comes to internationalization. But perhaps its importance does not carry the same weight in comparison with the economic and political justifications. If, in light of the pressing issues and challenges arising from culture-based shocks within and between countries, there will be more interest and importance attached to social and cultural logics still to be seen,

as we have observed in the thoughtfully planned and carefully conducted activities of the OIE, which, in turn, is widely recognized by the academic community. Internationalization, from whatever we have observed there, seems to arise from the engagement of the Subjects, but becomes vigorous under circumstances of strict, well-known processes of planning, development, evaluation and refinement, with a solid investment of the institution in creating adequate infrastructure to account for all of the connected processes that allow for internationalization to take Place in everyday life.

Another issue to be highlighted has to do with the cultural side of internationalization processes. One respondent states that the "international and cultural experience is the most important variable - because it is capable of generating social change. When the university does not engage in internationalization, everyone loses" (Director 2). As the interview with this Subject took Place, the impression of his understanding that universities cannot fulfill their mission without being "universal" or international in their way of relating to the world of ideas, facts and issues connected with an understanding that the links a public university has with the communities that allow for its existence could strengthen the conditions for the fulfillment of its mission at the same time that it could be strengthened by doing so. This produces a kind of virtuous cycle or dialogic relationship that advances the very mission of the institution and the response to issues that the society poses to the university.

A distinctive feature observed at UGA, on the other hand, has to do with how a concept of internalization unfolds as a set of actions and processes aimed at 
sharing experiences of internationalization within the university. One of the directors (Director 3) listed a number of ongoing actions aimed at sustaining and fostering the idea of internationalization within the premises of the university, a concept that relates directly with what Knight (2004) treats as internationalization at home. That director mentions that those actions are fundamental for the development of the identity of UGA as an international institution. To name a few examples, the centers have their own activities (e.g., International Day, Experiential Learning both/either domestic and/or abroad). Besides that, the OIE has a well established schedule, institutionally incorporated into the academic calendar, which includes events such as the International Street Festival, the International Week, and the International Coffee Hour, to name a few. As mentioned, these actions may characterize what some authors are defining as "Internationalization at Home (IaH)", which is "interpreted to be the creation of a culture or climate on campus that promotes and supports international/ intercultural understanding and focuses on campus-based activities" (Knight, 2004, p. 20). A similar perspective, which aligns to Knight's, proposes to redefine internationalization by adding up the set of actions that take Place on campus, arguing that such "definition stresses intentional inclusion of international and intercultural aspects into curricula in a purposeful way. [In that sense], Internationalization at Home is the purposeful integration of international and intercultural dimensions into the formal and informal curriculum for all students within domestic learning environments" (Beelen and Jones, 2015, p. 69).

In spite of the efforts done by the academic community to foster a positive and welcoming environment for internationalization both abroad and at home, all of the respondents expressed serious concern with recent political restrictions imposed by the federal administration, which potentially affect the image of the United States as a nation with open borders to the free flow of individuals, especially as far as Higher Education is concerned. Some even mention that negative effects and impacts of such restrictions have already been felt on the recruitment-abroad side of the internationalization process.

Even though the engagement in internationalization has been referred to as an essential and continuous piece to accomplish the mission of the university (Director 4), all of the interviews made it clear that it is not considered a requirement. Whenever internationalization abroad is concerned, a very important UGA program is Education Abroad Students, that aims to introduce students into international experiences, which could be Short Term or Semester Programs. The OIE has a GoAbroad Portal that, in addition to helping students make their choices, also integrates UGA information and monitoring systems. From our data collection process, we found solid indication that the intentionally planned actions carried out or facilitated by the OIE seem to play a major role within the internationalization of UGA by pragmatically expressing a concept of internationalization which implies that the infrastructure, the administrative systems and the supporting structures made available by the OIE seem to provide the necessary ground for the interactions at the academic and scientific level to take Place.

Interviewees were unanimous in indicating Education Abroad Students as UGA's largest internationalization program for undergraduates. This program is 
designed to offer students international opportunities, but on the other hand it is an important form of visibility for the university, which maintains three campi abroad: one in Cortona (Italy), one in Monteverde (Costa Rica), and another one in Oxford (United Kingdom), respectively created in 1970, 2002 and 2014. As indicated by all respondents, this is a highly consolidated student mobility program at the university. The Strategic Plan — as referred by at least two interviewees - starts with this experience as step towards advancing to international cooperation through research. In this sense, we identify Research as a substantive category. However, it is a cross-sectional category in the context of internationalization of Higher Education.

Hence, research, the third substantive category identified, is understood as the production of scientific knowledge. More specifically, we see research as an interdisciplinary endeavor, due to the nature of contemporary complexity (Raynaut, 2011), which generates an increasing demand to cross disciplinary borders. The production of knowledge requires dialogue beyond geographical and disciplinary boundaries and at the university it becomes the driving force that moves internationalization. Our assumption is that individual initiatives are driven by research interests and needs, and, in its turn, the search for research funding is highly focused on international cooperation.

However, two points are highlighted here. The first one is the characteristic of the research, which is, to the best of our understanding, essentially interdisciplinary. The second one has to do with the privilege of the hard sciences over other domains of knowledge. In this sense, the interviews pointed to the hegemony of the hard sciences in the western paradigm and the capacity of researchers of that scientific field to capture the majority of the resources. This paradigm (Santos, 2015) - at the genesis of the modernity - is still prevalent nowadays within the space of Higher Education. Some interviewees (for example, Faculty 1 and 2) recalled that at UGA, researchers are encouraged to seek for international partnerships and advance in joint research that could eventually give UGA more visibility, which is added by the assertion that at the university "we seek resources in our areas of excellence" (Director 8).

Despite the dominance of the hard sciences in processes of internationalization, a very important landmark of the internationalization at UGA is the

Portuguese Flagship Program (PFP) in collaboration with The Language Flagship ${ }^{6}$ at the University of Georgia [which] is the first and only of its kind. Intended for UGA undergraduate students with a unique commitment to reach the highest levels of Portuguese and apply those skills in a professional context, the PFP offers an unprecedented opportunity for motivated students to internationalize their academic experience. (LFP, 2018)

6 The Language Flagship began as a small pilot project to challenge a few United States universities to build programs of advanced language education. The first flagship grants were awarded in 2002, and the challenge was great: create advanced programs of language study and graduate students with professional proficiency. The languages chosen were Korean, Arabic, Russian, and Chinese. Today the Language Flagship currently boasts 25 Flagship Centers, providing a pathway to professional-level proficiency in Arabic, Chinese, Korean, Persian, Portuguese, Russian, and Turkish. A program with the support of the National Security Education Program (NSEP) (TLF, 2018). 
Currently this is one of the most vigorous exchange programs at UGA, providing, in addition to relevant international academic experiences to students, important experiences as to how to equalize cultural differences between distinct university systems, which reveals, among other things, a very keen sense of opportunity observed at UGA. Such sense could be related to Mignolo's (2017) point of view about what it takes to have a decolonial approach, by referring to the very existence of borderline zones ${ }^{7}$ of the global political society.

One last issue to be dealt with has to do with rankings, which are inherently competitive elements of a highly disputed territory of the struggle for hegemony within the knowledge society. From the interviews, one can infer that the institution is not driven by the rankings, but, on the other hand, there is some sensibility to them, especially whenever the relative position occupied by an institution in those rankings could help project a positive image of the institution to the different publics with which it relates to.

To sum up, the three categories - Subject, Place, and Research - relate to and provide support for two other analytical categories we have been working with when doing research about the internationalization of Higher Education, namely policies and actions. We also feel tempted to point out that, by looking at concepts and strategies brought about by the data collection process and synthetically organized on Table 3, we find strong support for the idea of a different way of looking at internationalization, one that underlines and emphasizes the importance of the Subject rather than shadowing or denying it.

Table 3 - Synthesis substantives categories.

\begin{tabular}{c|c}
\hline Categories & Highlight \\
\hline \multirow{2}{*}{ Subject } & Autonomy/ Initiative/ Expertise \\
& Mobility - students/ professors/ researchers \\
Strategic planning \\
Trust and ethics - search for solutions \\
Sensitive to the Place it occupies
\end{tabular}

Source: Research data (2018).

Elaborated by the authors.

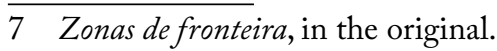




\section{CONCLUSION}

From the data we have been able to gather, we infer that the underlying assumption around the process of internationalization at the UGA is that the concept of building some sort of global citizenship is at the very core of the policies and of the actions in effect at the institution, and that the international and cultural experience is capable of generating the proper means and the engagement through which the university stands out as the locus capable of generating social change.

However, we found out the political momentum in the United States somewhat imposes a review of processes related to an increasing feeling of the closure of borders, which implies additional - but not necessarily unsolvable - difficulties to mobilize partnerships inland and abroad. We also infer that the concept of internationalization is still closely linked to an idea of the strength in student and faculty mobility, probably due to the visibility that this kind of program generates, but also because of its tradition and excellence at UGA, which even reports participants who are the second generation in their families to join the mobility program of the university.

Even though the engagement in internationalization has not been treated as a requirement, faculty, staff and directors mention a lively encouragement for internationalization, mostly through the intentionally and carefully implemented administrative structure that facilitates processes related to internationalizing the university, but also because of desirable results - from the point of view of the institution - of engaging in international programs, activities and partnerships, which is the case of the very likely positive improvement of the institutional performance in rankings.

In relation to the formulation of policies, the data analysis suggests an effort to centralize the definition of policies in the president's office, not only by mobilizing stakeholders entitled by the dynamics of institutional life, but also by gathering expertise and concrete initiatives in a way that fosters an actual sense of coordination of concerted actions and processes. This, in its turn, seems to create a sense of belonging to which we have already referred to.

From the analysis carried out, three substantive categories have been identified and those categories, in their turn, express concepts that support policies and actions of internationalization: Subject, Place and Research. On one hand, those are constitutive categories of an in-depth understanding of internationalization from within the institution in which the research has been developed. On the other hand, they are categories that allow to go beyond a mere investigative issue, opening up possibilities of self-reflection in terms of the Brazilian and Latin American contexts, both as researchers working with issues in the field of Higher Education and as Subjects of and within the process of producing knowledge either in the periphery or in hegemonic centers. The path taken so far has allowed to look back at our own work and at how we conceptualize internationalization anchored by a decolonial approach. That, in its turn, allows for the (re)placing of notion of Subject to the central Place from where the hegemonic discourse of globalization consistently intends to have it removed from. By identifying those three categories 
as substantive ones, we identify concrete possibilities that the internationalization of Higher Education offers as space for tensions in the production of knowledge.

In our effort to explore concepts, policies and actions about internationalization of Higher Education, we came to conclude that the substantives categories identified - Subject, Place and Research — seem to invest the debate with multiple possibilities of meaning. The Subjects, rather than individuals devoid of their identity, can be seen as the starting point and driving force of processes of internationalization. Places are spaces that are inherently filled with both contradictions and possibilities, and that bring together Subjects that can count on support and means to build bridges for understanding in borderline zones, by acting out interdisciplinary joint efforts of Research to address complex issues that affect mankind as a whole. It is important, however, that those categories could be revisited buy other researchers in and from other contexts, like Brazil and Latin America, so that we could advance in the dialogues that refer to the internationalization of Higher Education. In that respect, however, one must find out to what extent we - as Subjects in the Places we occupy - are willing to accept such challenge.

\section{ACKNOWLEDGEMENTS}

We are grateful to the support of Conselho Nacional de Desenvolvimento Científico e Tecnológico (National Council of Scientific and Technological Development) (CNPq/Brazil), grant 446097/2014, Edital Universal 14/2014, without which this research work could not be done. We have no words to express how grateful we are to the UGA - especially the ones who make its history on a daily basis - for the opportunity of research; in special to the Department of Lifelong Education, Administration, and Policy, through the Qualitative Research Graduate Program; to Dr Kathleen deMarrais; and to the Office of International Education for the invaluable support and inspiring guidance along the process.

\section{REFERENCES}

ACE - AMERICAN COUNCIL ON EDUCATION. Mapping internationalization on US. Washington, DC: Sponsor Nativas, 2017.

ALTBACH, P. G. Globalization and the university: myths and realities in an unequal world. Tertiary Education \& Management, Netherlands, v. 10, n. 1, p. 3-25, 2004. https://doi.org/10.1080/13583883.2004.9967114

ALTBACH, P. G.; SALMI, J. (ed.). The road to academic excellence. The making of world-class research universities. The International Bank for Reconstruction and Development. Washington, DC: The World Bank, 2011.

BEELEN, J.; JONES, E. Redefining internationalization at home. In: CURAJ, A. et al. (ed.). The European Higher Education area: between critical reflections and future policies. Springer: Cham, 2015. p. 59-72. 
BOGDAN, R. C.; BIKLEN, S. K. Qualitative research for education: an introduction to theory and methods. 5th ed. Boston: Allyn \& Bacon, 2017.

CRES - CONFERENCIA REGIONAL DE EDUCACIÓN SUPERIOR. Declaração. In: CONFERÊNCIA REGIONAL DE EDUCAÇÃO SUPERIOR PARA A AMÉRICA LATINA E O CARIBE, 3., 2018. Córdoba, Argentina: 14 jun. 2018.

DeMARRAIS, K. Qualitative interview studies: learning through experience. In: DeMARRAIS, K.; LAPAN, S. D. Foundations for research methods of inquiry in education and the social sciences. Mahwah, NJ: Lawrence Erlbaum Associates, 2004. p. 51-68.

DUSSEL, E. Filosofia da libertação. São Paulo: Edições Loyola, 1977.

DUSSEL, E. Método para uma filosofia da libertação. São Paulo: Edições Loyola, 1986.

EUA - EUROPEAN UNIVERSITY ASSOCIATION. Internationalization in European Higher Education: European policies, institutional strategies and EUA support. Brussels: European University Association, 2013.

FREIRE, P. Pedagogia da autonomia: saberes necessários à prática educativa. 50. ed. Rio de Janeiro: Paz e Terra, 2015.

FROUMIN, I.; LISYUTKIN, M. Excellence-driven policies and initiatives in the context of Bologna Process: rationale, design, implementation and outcomes. In: CURAJ, A. et al. (ed.). The European Higher Education area: between critical reflections and future policies. Springer: Cham, 2015. p. 248-265.

HAZELKORN, E. Rankings and the reshaping of Higher Education: the battle for world class excellence. Basingstoke: Palgrave Macmillan, 2011.

HORIZON 2020. Policies: information and services. Brussels: 2018. Available at: https://ec.europa.eu/programmes/horizon2020/en. Access in: Feb 10, 2018.

JONES, E.; COELEN, R.; BEELEN, J.; WIT, H. (ed.). Global perspectives on Higher Education. Boston: Center for International Higher Education, 2016. (Global Perspective in Higher Education, v. 34).

KNIGHT, J. Internationalization remodeled: definition, approaches, and rationales. Journal of Studies in International Education, Thousand Oaks, v. 8, n. 5, p. 5-31, 2004. https://doi.org/10.1177/1028315303260832

LFP - LANGUAGE FLAGSHIP PROGRAM. Portuguese Flagship Program. Available at: http://www.portflagship.org. Access in: Mar. 10, 2018.

MAXWELL, J. A. Qualitative research design: an interactive approach.3. ed. London: Sage Publications, 2013. (Applied Social Research Methods, v. 41).

MIGNOLO, W. D. Colonialidade: o lado mais escuro da modernidade. RBCS Revista Brasileira de Ciências Sociais, São Paulo, v. 32, n. 94, p. 1-18, jun. 2017. http://dx.doi.org/10.17666/329402/2017

MINAYO, M. C. S. O desafio do conhecimento: pesquisa social em saúde. Rio de Janeiro: HUCITEC; ABRASCO, 2000. 
PETERS, M. A. Manifesto for the postcolonial university. Educational Philosophy and Theory, London, v. 51, n. 2, p. 142-148, 2017. https://doi.org/10.1080/001 31857.2017.1388660

RAYNAUT, C. Interdisciplinaridade: mundo contemporâneo, complexidade e desafios à produção e à aplicação de conhecimentos. In: PHLILIPPI JR, A.; NETO, A. J. S. Interdisciplinaridade em ciência, tecnologia \& inovação. Barueri: Manole, 2011. p. 69-105.

ROULSTON, K. Reflective interviewing: a guide to theory and practice. Los Angeles: Sage Publications, 2010.

SALMI,J.The challenge of establishing world-class universities. In: INTERNATIONAL CONFERENCE ON WORLD-CLASS UNIVERSITIES (WCU-3), 3., 2009, Shanghai. Annals [...]. Shanghai: Thomson Reuters, 2-4 Nov., 2009.

SANTOS, M. Por uma outra globalização: do pensamento único à consciência universal. Rio de Janeiro: Record, 2015.

TLF - THE LANGUAGE FLAGSHIP. The flagship history. Available at: https://www.thelanguageflagship.org/content/flagship-history. Access in: May 20, 2018. UGA - UNIVERSITY OF GEORGIA. Strategic plan 2020: building on excellence. Athens: UGA, Oct. 30, 2012.

UGA - UNIVERSITY OF GEORGIA. Initiating academic partnerships. Athens: UGA. Available at: http://international.uga.edu/partnerships/develop-partnerships. Access in: May 20, 2018.

UGA - UNIVERSITY OF GEORGIA . Office of Institutional Diversity. Athens: UGA. Available at: http://diversity.uga.edu/index.php/about/welcome. Access in: Mar. 10, 2018.

UGA - UNIVERSITY OF GEORGIA. Facts. Athens: UGA. Available at: http://www.uga.edu/profile/pride/. Access in: May 20, 2018.

UGA - UNIVERSITY OF GEORGIA. By the numbers. Athens: UGA. Available at: http://www.uga.edu/profile/facts/. Access in: May 5, 2018.

WIELEWICKI, H. G.; RUBIN-OLIVEIRA, M. Internacionalização da educação superior: processo de Bolonha. Ensaio: Avaliação e Políticas Públicas em Educação, Rio de Janeiro, v. 18, n. 67, p. 215-234, abr./jun. 2010. http://dx.doi.org/10.1590/ S0104-40362010010700001

WIT, H. Globalisation and internationalisation of Higher Education. Revista de Universidad y Sociedad del Conocimiento(RUSC), Barcelona,v. 8, n. 2,p. 241-248, 2011. Available at: https://www.raco.cat/index.php/RUSC/article/viewFile/254141/340980. Access in: Jan. 10, 2018.

ZAJDA, J.; RUST, V. (ed.). Globalization and Higher Education reforms. Switzerland: Springer, 2016. (The Globalization, Comparative Education and Policy Research Series, 15). 


\section{ABOUT THE AUTHORS}

Marlize Rubin-Oliveira has a doctorate in education from the Universidade Federal do Rio Grande do Sul (UFRGS). She is a professor at the Universidade Tecnológica Federal do Paraná (UTFPR).

E-mail: rubin@utfpr.edu.br

Hamilton de Godoy Wielewicki has a doctorate in education from the Universidade Federal do Rio Grande do Sul (UFRGS). He is a professor at the Universidade Federal de Santa Catarina (UFSC).

E-mail: h.g.wielewicki@ufsc.br

Received on June 25, 2018

Approved on March 15, 2019 